The $B D J$ News section accepts items that include general news, latest research and diary events that interest our readers. Press releases or articles may be edited, and should include a colour photograph if possible. Please direct your correspondence to the News Editor, Arveen Bajaj at the $B D J$, The Macmillan Building, 4 Crinan Street, London N19XW or by email to bdj@bda.org

\section{Treatment will seek out bacteria}

A team of researchers have created a new smart anti-microbial treatment that can be chemically programmed in the laboratory to seek out and kill a specific cavity-causing species of bacteria, leaving the good bacteria untouched.

The team developed the experimental treatment called STAMP. The acronym stands for Specifically Targeted Antimicrobial Peptides. Like its postal namesake, STAMPs have a two-sided structure, the first is the short homing sequence of a pheromone, a signaling chemical that can be as unique as a fingerprint to a bacterium and assures the STAMP will find its target. The second is a small anti-microbial bomb that is chemically linked to the homing sequence and kills the bacterium upon delivery.

While scientists have succeeded in the past in targeting specific bacteria in the laboratory, the team claim that this report is unique because of the STAMPs themselves which generally consist of less than 25 amino acids, compared to the relatively bulky, bacteria-seeking antibodies that have fascinated scientists for years. Because of their streamlined design, STAMPs can also be efficiently and rapidly produced on automated solidphase chemistry machines designed to synthesize small molecules under 100 amino acids, called peptides.

As reported online in the journal Antimicrobial Agents and Chemotherapy, the scientists found they could eliminate the cavity-associated oral bacterium Steptococcus mutans within 30 seconds from an oral biofilm without any collateral damage to related but non-pathogenic species attached nearby.

\title{
Distinction awarded
}

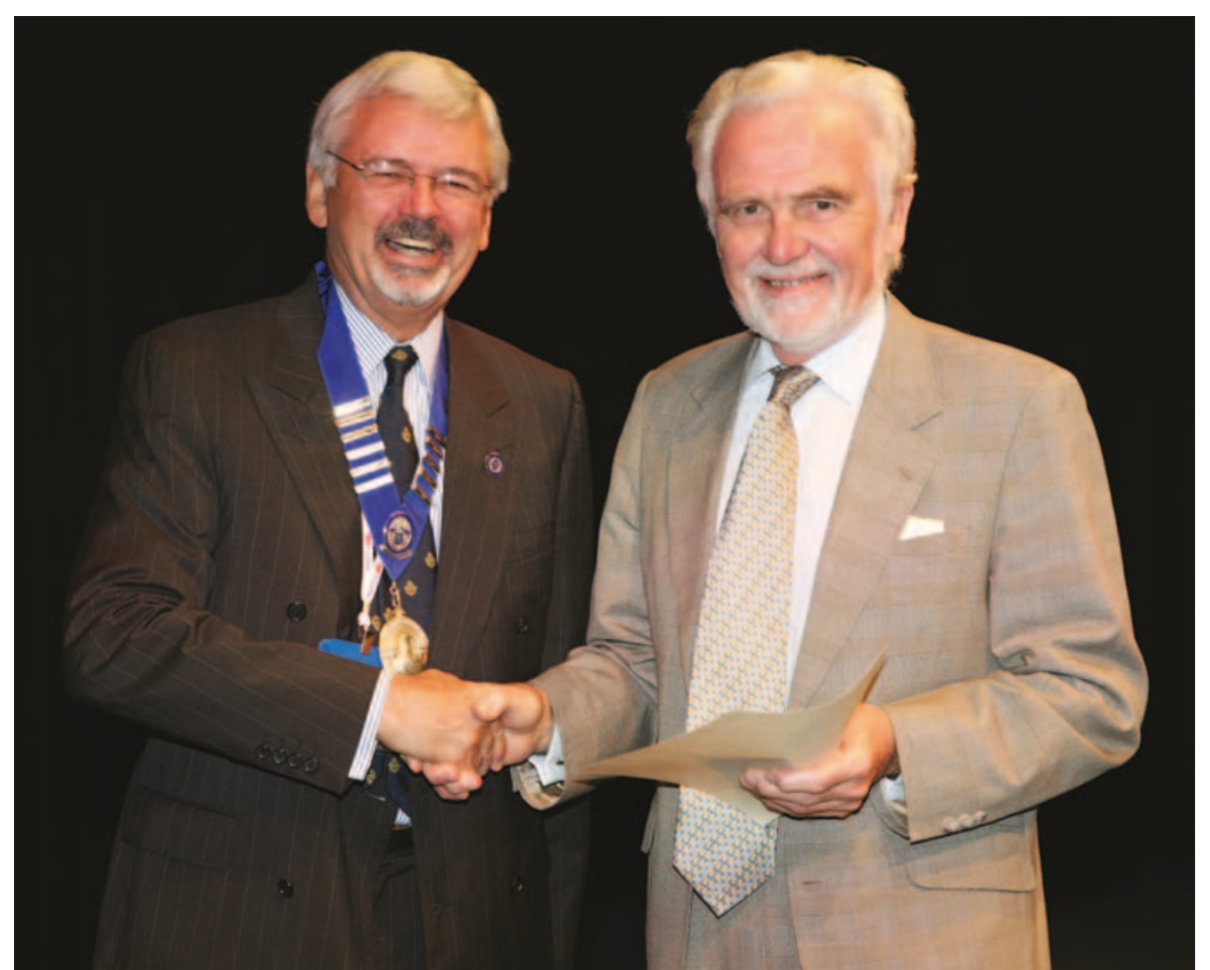

Ray Reed, Lead Postgraduate Dean for Orthodontics, has been awarded the British Orthodontic Society's Distinction Award for his outstanding contribution to the specialty.

The award was made at the British Orthodontic Conference in Edinburgh by Ken Lumsden, President of the Society. Ray has been Dean of the Dental Faculty at the Royal College of Physicians and Surgeons, Glasgow, a long-standing member of the British Dental Association's Central Committee for Hospital Dental Services and a member of the General Dental Council. The Distinction Award is made annually to someone who has worked for the specialty outside BOS. However, Ray was also thanked for the positive role he played in the formation of the Society 11 years ago. Pictured, Ray Reed (right) with Ken Lumsden.

\section{ADI launches research grant}

The Association of Dental Implantology (ADI) has announced the introduction of it's biennial research grant. Open to all full ADI members, $£ 10,000$ (or two grants of $£ 5,000$ each) will be available to the successful applicant/s who illustrates the most original and innovative proposal.

Research grant committee chairman Dr Michael Norton said, "This award not only represents another milestone in the development of the ADI but demonstrates its firm commitment to education, research and encouragement of its members to contribute to the future evolution of implant therapy and related sciences." The closing date for applications is 28 February 2007. Members can find out more information on the ADI website, www.adi.org.uk, or by calling 02084875555. 


\section{Common antacids could help keep gingivitis at bay}

Chemicals commonly used to treat heartburn also display fighting power against the oral bacteria linked with gum disease, according to researchers at the University of Rochester Medical Center and Göteborg University in Sweden.

A study published in November's Archives of Oral Biology, explores how the active ingredients in popular antacids could help fend off gingivitis. If the work holds up in subsequent studies in people, the compounds could one day find themselves widely available in oral care products like toothpaste and mouthwashes.

"The American diet and the constant drip of sugar allows little time for the natural repair of teeth. All day, it's a cycle of acidic erosion and repair - or at least, it should be - but our constant sucking on hard candy and guzzling sodas with high fructose syrups leaves little time for repair," said the study's lead author, Robert Marquis, Ph.D, of the University of Rochester Medical Center, NY, USA.

The team studied a compound known as lansoprazole, part of a family of compounds known as benzimidazoles that already have a range of uses, primarily controlling stomach hyperacidity and killing Helicobacter pylori (the bacteria responsible for stomach ulcers).

The researchers decided to focus on Fusobacterium nucleatum, an especially hardy bacterial troublemaker that plays a crucial role in setting the stage for gum disease. When the oral environment becomes acidic lansoprazole is chemically modified to kick into action, disabling $F$. nucleatum and preventing it from producing toxins or serving as a

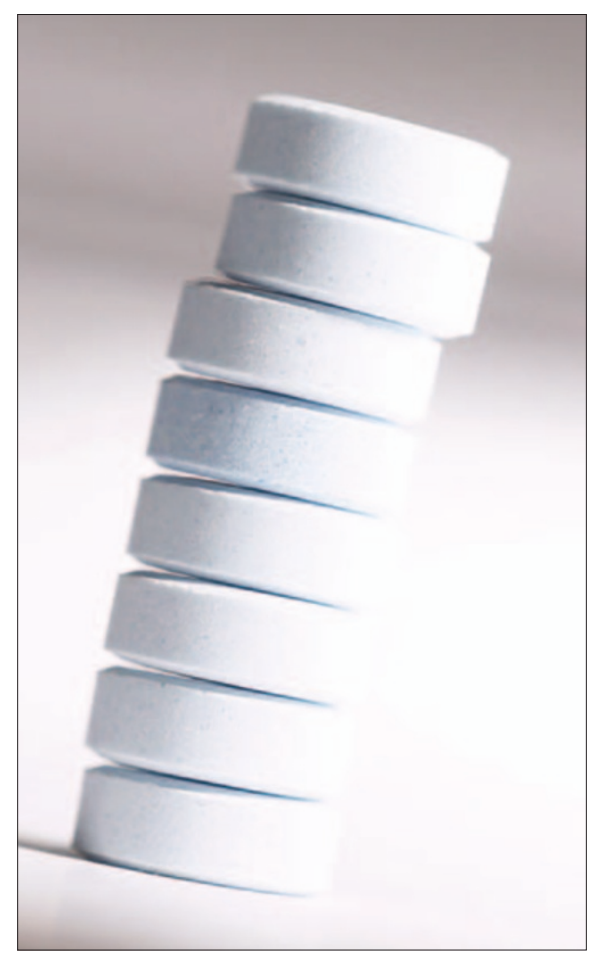

landing site. Once the oral environment returns to normal, the lansoprazole simply switches off.

"Benzimidazoles aren't just for acidreflux anymore," said Dr Marquis, whose research project was supported by the US National Institute of Dental and Craniofacial Research. "We've shown their promise for preventing cavities in previous research, and now, perhaps even some protective benefits to guard against gingivitis. It's not unthinkable that one day these compounds might be more broadly used to promote dental health in toothpastes and mouthwashes."

\section{BDA update}

The Annual General Meeting of the BDA's Dental Academic Staff Group will be held on 29 November in the Lecture Theatre, BDA Wimpole Street at $10.30 \mathrm{am}$.

All members of the Group are welcome to attend and should confirm their attendance by contacting Sue Jones, Secretary DASG, on 02920496174 or via email at sue. jones@bda.org.

Details of the agenda and meeting are posted on the web page of the Group. Please see http://www.bda.org/advice/ quicknav_advice.cfm?PID = salariedtemplate1.cfm\&CONTENTID $=474$ for further details.

In other news from the Association, the BDA is negotiating a new contract and associated pay scale with NHS Employers for dentists working in salaried primary dental care in England. The aim is that this will be implemented from April 2007.

When the contract has been agreed by both parties, the BDA will ballot members and non members. It is anticipated that a ballot will take place in January 2007.

To ensure that the BDA has accurate and up to date contact details, please email the following information to SPDCSBallot@bda.org:
1. Full name
2. GDC number
3. Member - Yes/No
4. Full postal address
5. Employing Trust
6. Grade
7. Phone number and fax
8. Email address. 


\section{CPD guidance}

New guidance for dentists on continuing professional development (CPD) has been published by the General Dental Council (GDC). Continuing professional development for dentists explains what dentists need to do to meet the requirements of the GDC's compulsory CPD scheme.

The GDC is recommending that all dentists carry out verifiable CPD in the following core subjects from the beginning of their next CPD cycle: medical emergencies, disinfection and decontamination, and radiography and radiation protection.

In addition, the GDC recommends that dentists working in a clinical environment carry out CPD (verifiable or general) to make sure that they are up to date in legal and ethical issues and handling complaints. For more details visit www. gdc-uk.org.

\section{Marking 41 years of service}

Mr Patrick ('Pat') Lilly retired at the end of September 2006 after 41 years of service at Glasgow Dental Hospital et School. An immensely popular character with staff and students alike, Pat was employed for 36 years as a University Dental Instructor.

In addition to his role in direct student instruction, he played a major role in developing audio-visual training materials for prosthodontics teaching in Glasgow. He is an active member of the Society of University Dental Instructors (SUDI), of which he was President in 2003. Pat has also been a long-standing member of the Henry Noble History of Dentistry Research Group, for which he has researched many topics over the years. In recognition of his long and loyal service, colleagues organised a farewell social gathering on 27
September. He is pictured with Professor Jeremy Bagg, Head of the Dental School.

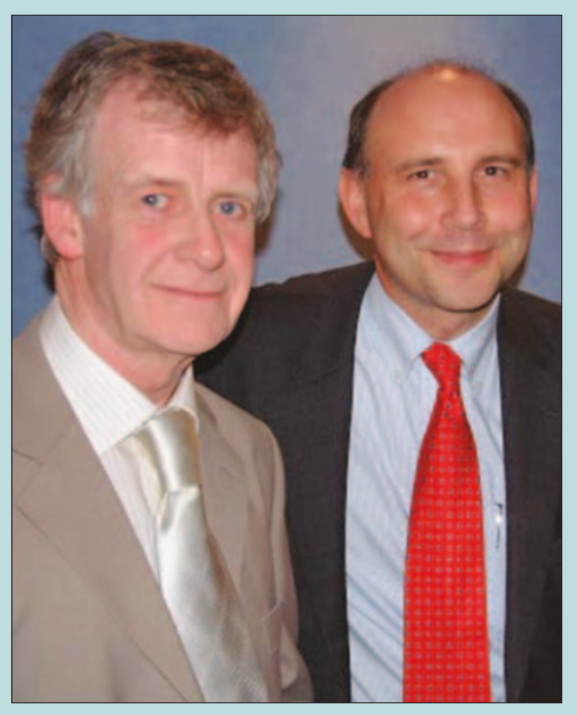

\section{Make a difference to the homeless at Christmas}

Crisis, the national homelessness charity, is urgently appealing for dentists, dental nurses and hygienists to volunteer their skills to help homeless people this Christmas. The charity says that up to 1,500 homeless and vulnerably housed people will visit the 35th Crisis Open Christmas this year, running from 23 -30 December. Some will be rough sleepers but the majority will be hidden homeless people who may live in hostels, bed and breakfast

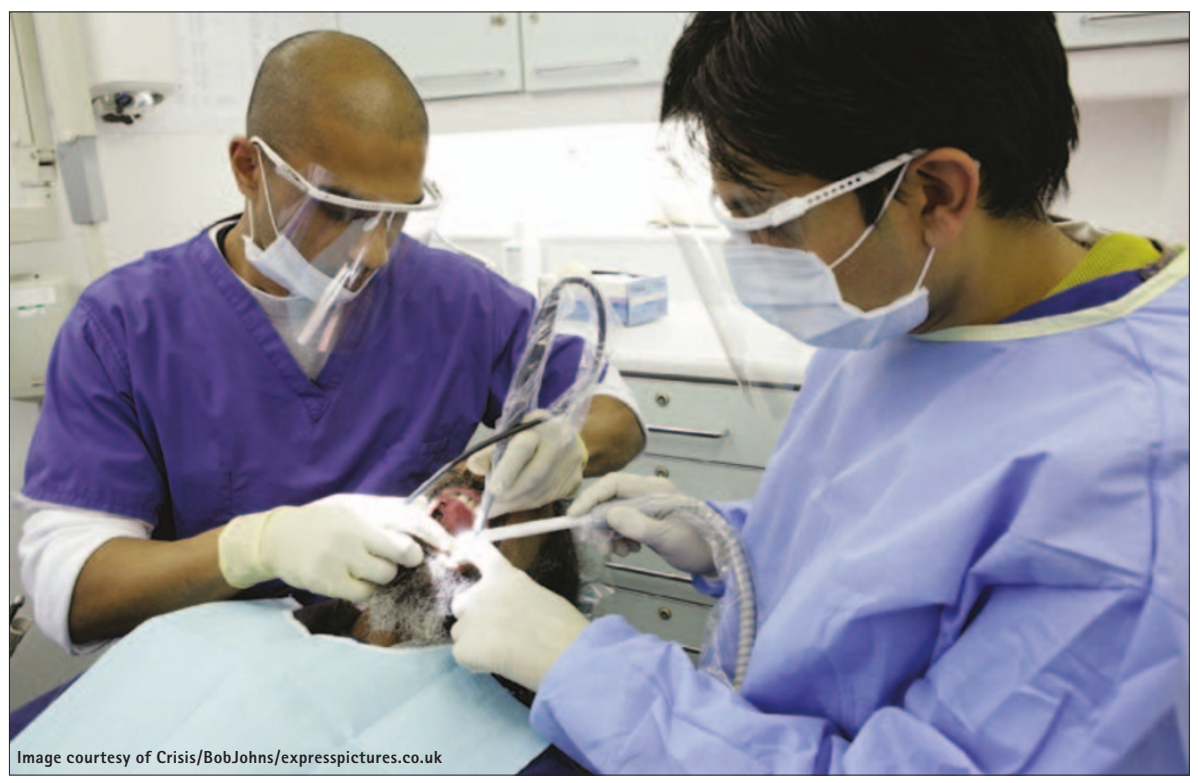

accommodation or on friends' and families' floors.

Held at seven venues across London, the Crisis Open Christmas centres provide an alternative family for many homeless and vulnerably housed people who feel particularly lonely and isolated over the Christmas period. As well as companionship, the centres provide guests with a range of essential services, whether it is housing and benefits advice, full health checks or access to the Crisis Learning
Zones for training and further education. According to Crisis, coming to the Open Christmas is the first step many guests take towards rebuilding their lives and it hopes that many of the homeless people it sees over the Christmas week will be inspired to take up year-round opportunities at Crisis such as the workshops and courses available in its Skylight centre. Its ultimate aim is to reconnect homeless people with the skills to secure their own independent futures.

Dentistry is an integral part of the medical services on offer and many guests may not have had access to dental services for some time. Dentists, dental nurses and hygienists are urgently needed to volunteer for a range of shifts between 23-29 December. Last year 180 guests visited the dentist service and 80 teeth were extracted.

Fuz Jamall, Dental Service Organiser said, "We are on the look out for dentists, therapists and hygienists who are qualified and are willing to look after patients at all levels. Our aim is to take total care of everyone we see and provide them with the treatment they deserve."

Crisis Open Christmas would not be possible without the help of around 5,000 volunteers who generously donate their time and skills over the Christmas week and the dental team are a key part of the volunteer workforce. To find out more about volunteering call 0207426 3872, email volunteering@crisis.org.uk or apply online at www.crisis.org.uk/ volunteering. 


\section{DIARY}

November

Health Protection Agency: Laser and IPL Sources Safety Training for Medical and Cosmetic Applications

Venue: HPA Radiation Protection Division, Leeds

Date: 28 November 2006

Telephone: 01132679041

www.hpa.org.uk

December

LDC officials' day 2006

Date: 1 December 2006

Venue: Tower Hotel, London

www.bda-events.org

January

1st International meeting on Cold Laser

Therapy in Dentistry

Date: 18 January 2007

Venue: New Orleans, USA

Tel/Fax: (888) 891-6485 5th Annual North American Orthodontic Conference for Full Face Orthodontic Study Group

Date: 19-21 January 2007

Venue: New Orleans, USA

Tel/Fax: (888) 891-6485

May

ADI 20th Anniversary Congress

Date: 3-5 May 2007

Venue: ICC in Birmingham

www.adi.org.uk

June

14th Annual Congress of the Turkish Dental Association

Date: 11-17 June 2007

Venue: Lütfi Kirdar Convention Center, Istanbul, Turkey

Email: tdbkongresi.com

www.tdbkongresi.com

\section{Improve nutrition for better oral health}

Latest research from the British Dental Association (BDA) and Wrigley Oral Healthcare in Action (OHA) has found that nutrition is now a core factor for dentists when assessing their patients oral health.

Results from the survey, which was carried out at this year's BDA Conference, show that over $40 \%$ of dentists are seeing over 21 patients per week for whom nutritional advice would help improve their oral care routine.

Just over $60 \%$ of the dentists

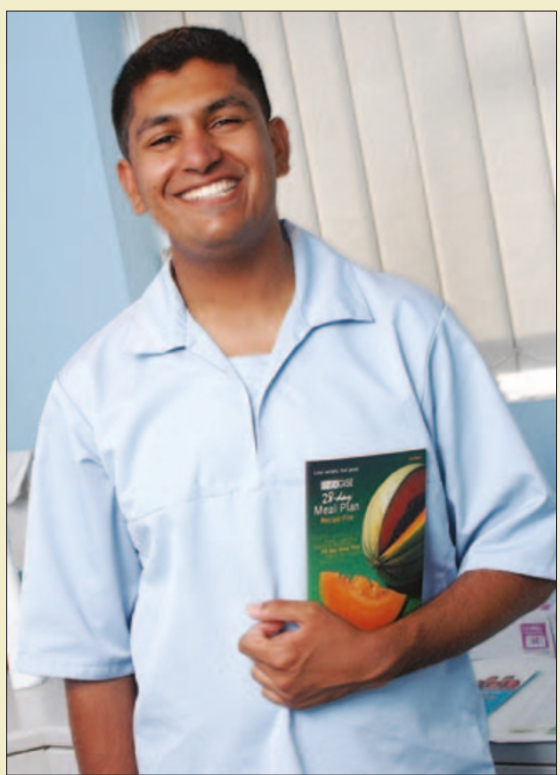

Dentist Kevel Shah from Amwell Street Dental Practice in Hertfordshire surveyed felt they did not have enough information to offer advice on this subject to their patients. Nutritionist Penny Hunking said, "Nutrition and a healthy balanced diet is extremely important in the care of our mouth, teeth and gums. There is no doubt that poor diet can lead to poor oral health and it is essential for dentists to have this information to hand so they know how best to advise their patients. With today's busy lifestyles people are eating more convenience food and snacks, often with high sugar contents. They need advice on how a good diet can help maintain oral health."

Wrigley OHA randomly selected a dentist who signed up to the Wrigley OHA programme at the BDA conference to benefit from a session with Penny at their practice. Penny ran a session on diet and nutrition, and particularly their impact on oral health, with winner Kevel Shah and his team at Amwell Street Dental Practice in Hertfordshire.

The aim of the Wrigley OHA Programme is to help promote better oral healthcare and the company provides patients and professionals with practical resources and materials on oral care in a way that is relevant to today's lifestyle and needs.

To find out more about the programme visit www.BetterOralHealth. info or call free on 08000564563. 